\title{
MAGNETIC SURVEY AND GEOLOGY OF THE \\ STAGER AREA, IRON COUNTY MICHIGAN
}

By

S. E. Good and F. J. Pettijohn 
UNITED STATES DEPARTMENT OF THE INTERIOR

\author{
J. A. Krug, Secretary \\ GE O L O G I A L S UR VEY \\ W. Ei. Wrather, Director
}

WASHINGTON, D. C.

Free on application to the Director, Geological Survey, Washington 25, D. C. 


\section{MAGNETIC SURVEY AND GEOLOGY OF THE STAGER AREA IRON COUNTY, MICHIGAN}

By

S. E. Good and F. J. Pettijohn

CONTENTS

\begin{tabular}{|c|c|}
\hline Page & Page \\
\hline Introduction................................................. 2 & Magnetic anomalies and structure................3 \\
\hline Field methods............................................. 2 & Exploration possibilities.............................4 \\
\hline Geology & \\
\hline
\end{tabular}

ILLUSTRATIONS

Figure 1. Index map.................................................................................................2

Plate 1. Geologic map of the Stager area, Iron County, Michigan .......................................... In pocket

2. Magnetic map of the Stager area, Iron County, Michigan. In two parts. (This map shows the magnetic data, and descriptions of the test pits, drill holes, and outcrops.).................................................... In pocket 


\section{INTRODUCTION}

The Stager iron-bearing area is in sec. $31, \mathrm{~T}$. $42 \mathrm{~N}$., R. 32 W., and in secs. 24,25 , and $36, T .42$ N., R. 33 W., in Iron County, Michigan. It extends from the Brule River to the Delphic mine (fig. 1). Stager, the settlement and junction point on the Chicago and Northwestern Railroad, is just beyond the east edge of the area mapped. This report is based principally on field work done in 1947 by S. E. Good assisted by J. J. Hill. The work is a part of a general restudy of the Iron River-Crystal Falls district by the U. S. Geological Survey in cooperation with the Geological Survey Division of the Michigan Department of Conservation.

The authors are indebted to Pickands, Mather and
Co. for information concerning the drilling done in sec. 24, T. 42 N., R. 33 W. Mr. C. E. Dutton and Mr. H. L. James of the U. S. Geological Survey have contributed to the work by their helpful criticisms and editorial suggestions.

There are no producing mines in the Stager area at the present time, but the Delphic mine is reported to have shipped 33,770 tons of nonbessemer hematite in the period 1883-1896.

\section{FIELD METHODS}

Most of the area was surveyed with a Wolfson vertical magnetometer. The results of this survey, together with descriptions of the outcrops

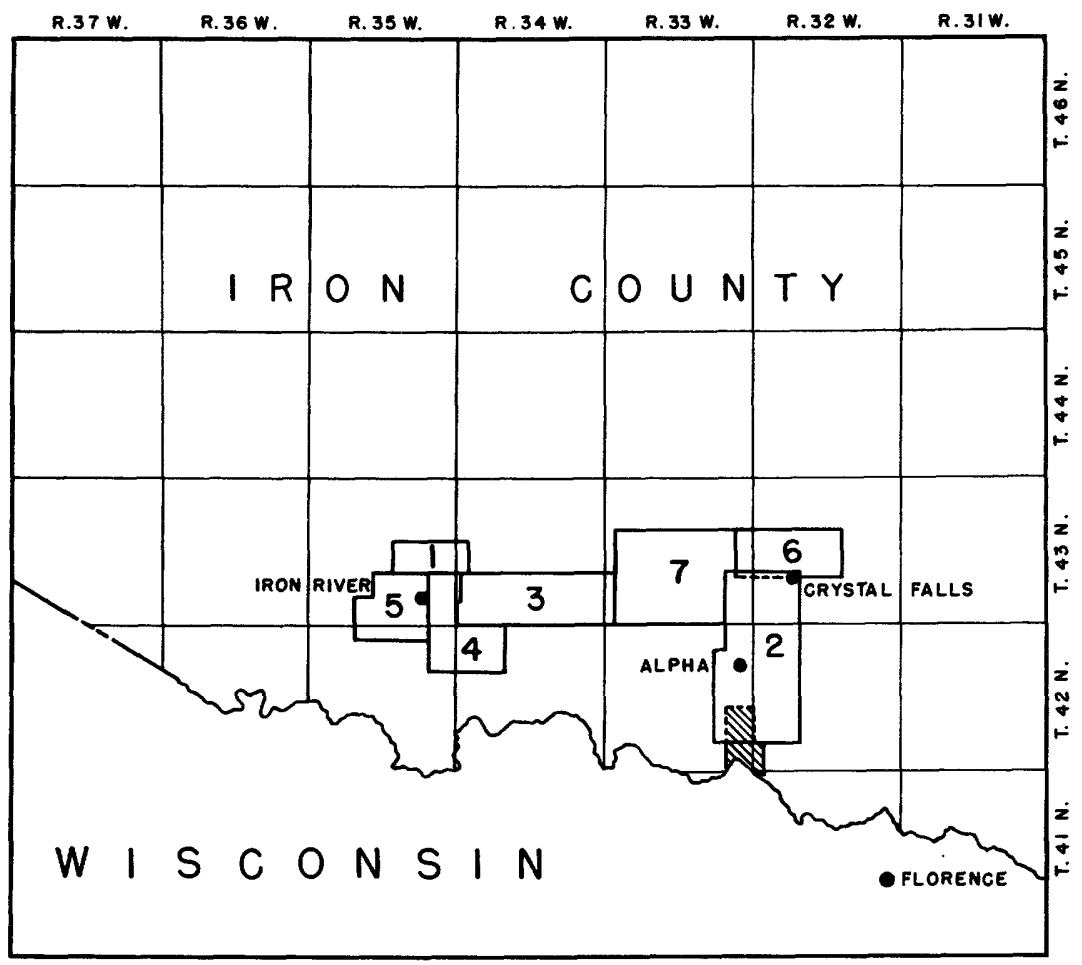

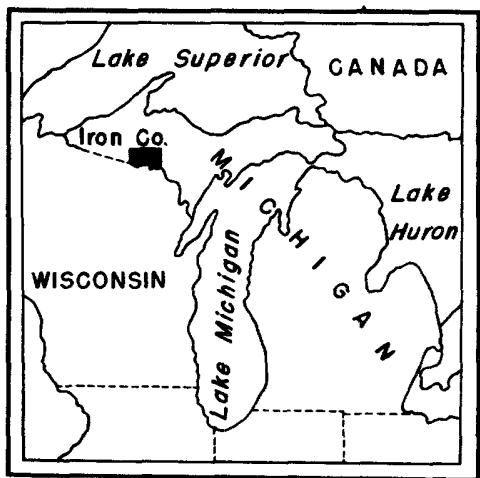

* Report in preparation
INDEX MAP OF IRON COUNTY MICHIGAN SHOWING AREAS COVERED BY PRELIMINARY REPORTS

Area covered by this report

Mineral Hills Area

Crystal Falls-Alpha Area

Ice Lake-Chicagon Creek Area

East-central and southeast

Iron River Area

Central Iron River Area

6 Northern Crystal Folls Area*

7 Work in progress

Figure 1. Index map 
test pits, and drill holes, are shown on plate 2. A few readings in sec. $24, T .42$ N., $R .33$ W., spaced 200 feet apart, were made with a Hotchkiss Superdip. The Superdip was oriented normal to the magnetic meridian and was calibrated against a vertical magnetometer. Readings were taken at 100-foot intervals with the magnetometer along lines approximately 200 feet apart. The values obtained were corrected for temueratures and diurnal changes and reduced to a common base station which is located about 200 feet west of the northeast corner of sec. 25, T. 42 N., R. $33 \mathrm{~W}$. This base was 522 gammas higher than the principal Iron County base station located in the NE $\frac{1}{4}$ sec. 28 , T. 43 N., R. $34 \mathrm{~W}$. The magnetic values, therefore, are shown as departures, measured in gammas, from the Iron County standard. Magnetic contours below 1,000 were drawn at 200 gamma intervals; above 1,000 gammas, only the 2,000 and 5,000 gamma contours are shown. The original data are given so that additional contour lines may be drawn if desired.

The position of all observation points was determined by pace and compass survey from established land survey lines. Though there may be some errors in the azimuths of the traverses run, these are not believed to be large because closures were small.

Outcrops and test pits shown on the maps were located during the magnetic survey. The drill hole information in the Delphic mine area is from the files of Pickands, Mather and Co.

\section{GEOLOGY}

The geology of the Stager area is shown on plate 1; it is similar to that of the Crystal Falls-Alpha area recently described $1 /$, and the reader is referred to that report for more complete descriptions of the rocks rocks involved. In most of the district rock outcrops are rare or small though the drift cover is apparently very thin (mostly less than 25 feet). Near the Brule River the terrane is more rugged and outcrops are, therefore, more numerous.

The area is underlain by a series of nearly vertical pre-Cambrian strata, striking approximately $\mathrm{N}$. $40^{\circ} \mathrm{W}$. The oldest of these, a greenstone, lies in the extreme northeast corner of the area. The younger strata, principally slates, which overlie the greenstone, are divided into two groups of beds by an intervening iron-formation. The lower beds are referred to as the footwall strata, whereas those that overlie the ironformation are designated as the hanging-wall strata. The slates and iron-formation are Huronian.

The greenstones are fine-grained rocks and are believed to be altered lava flows. They are probably of the same age as the greenstones of the Mastodon area, which is about a mile east of the area under consideration.

The footwall slates, which lie between the greenstone and the iron-formation, are so poorly exposed that detailed subdivision of these beds is not possible. The footwall strata just below the iron-formation are pyritic and graphitic as they are elsewhere in Iron County. Below the black graphitic slates are laminated gray slates. The thickness of the footwall slates is not certainly known, but it probably cannot be less than 1,000 feet.

The iron-formation is a bed, several hundred feet

1/ Pettifiohn, F. J., Geology of the Crystel Falls-Alnhe iron-bearin distriot: U. S. Geol. Surter Strategio l'inerals Investigations Preliminary "an $3-181,1946$. thick, which has now been traced without break from the Odgers mine near Crystal Falls to the Brule River. In the Stager area, it consists mainly of very very thin bedded, fine-grained, gray siderite and black chert. Only locally is the siderite oxidized to he matite.

The lowest portion of the hanging-wall strata, the basal breccia or graywacke noted in the Crystal Falls area, is either not present or was not recognized. The magnetic slate member, found elsewhere in Iron County, is present and is responsible for the principal magnetic anomalies of the Stager district. It lies at or very near the base of the hanging-wall strata. The youngest strata exposed are the graywackes and nonmagnetic slates of the upper part of the hanging-wall strata.

\section{MAGNETIC ANOMALIES AND STRUCTURE}

The magnetic anomalies of this area (see pl. 2) are due to (1) the magnetic slate member of the hanging-wall strata, and (2) the iron-formation. The anomalies are, for unknown reasons, very "spotty". This is especially true of the anomalies produced by the iron-formation. Although the anomalies related to the lower hanging-wall beds are less erratic, they are nonetheless discontinuous and of variable intensity.

The contacts between the iron-formation and adjacent strata are nowhere exposed. These contacts, however, can be closely interpolated between outcrops or test pits in some places, especially near the Brule River. They may be extrapolated from these established points. This extrapolation is guided not only by projection of the observed strikes but also by the magnetic data and to a lesser degree by the topography and drainage. In general the magnetic contours are parallel to the strike of the beds. In general also magnetic "crests" follow particular beds. The hanging-wall contact of the ironformation is much better controlled than is the footwall contact. The footwall contact can be located only approximately from a relatively few test pits and outcrops.

Inspection of the geologic and magnetic map (pl. 2) shows that although the observed strike of the exposed strata is about N. $45^{\circ} \mathrm{W}$. in most places, the trend of the formations as a whole is much more northerly. The nearly vertical iron-formation is displaced, at fairly regular intervals, either by taulting or by sharp flexures. The latter are in fact large-scale drag folds. The southernmost is a rather gentle flexure indicated in part by an offset in the course of McGovern Creek in sec. 36, T. 42 N., R. $33 \mathrm{~W}$., and also by a swing in the strike in the rocks exposed in the same area.

A more abrupt displacement occurs in the $\mathrm{NE} \frac{1}{4}$ sec. $25, T .42$ N., R. $33 \mathrm{~W}$. The offset in this place is thought to be due to a northwest plunging anticlinal-synclinal couple. This structure cannot be delineated with much accuracy. The marked magnetic anomaly associated with the basal member of the hanging-wall strata, which can be traced northwestward across most of the section, ends near the center of the NW $\frac{1}{4}$ of this section. The small magnetic "high" in the NW $\frac{1}{4} \mathrm{NE} \frac{1}{4}$ of the same section is thought to be due to the same bed as is the anomaly in the NW $\frac{1}{4}$ SW $\frac{1}{4}$ sec. $24, T .42$ N., R. 33 W. The strike of the beds exposed agrees with this interpretation. The marked angular divergence between slaty cleavage and bedding in the outcrops in the NW $\frac{1}{4}$ sec. $30, T .42$ N., R. 32 W., indicates these beds to be near a fold axis and thus confirm the postulated structure. 
The most northerly offset in the strata, near the Delphic mine, is thought to be due to a diagonal cross fault. It is thought that the magnetic anomalies of the NW $\frac{1}{4} S W \frac{1}{4}$ of sec. $24, T .42$ N., R. 33 W. and that in the $\mathrm{NE} \frac{1}{4}$ of SW $\frac{1}{4}$ of the same section are due to the same bed. If so, the offset relations between them seem better explained by faulting than by close folding.

\section{EXPLORATION PASSIBILITIES}

The conversion of the unoxidized iron-formation to ore involves oxidation of the carbonate to limonite or hematite and removal of the chert. In many places in IrO.l County the ore bodies so formed are located along the axes or "keels" of plunging synclines. In the Stager area, however, oxidized iron-formation is known in only two places, namely in the Delphic mine area of sec. 24, T. 42 N., R. 33 W., and locally in the test-pitted area, in the W $\frac{1}{2} \mathrm{NE} \frac{1}{4}$ of sec. $25, T .42$ N., R. $33 \mathrm{~W}$., known as the Wakefield exploration. To date, drilling in the Delphic area has failed to disclose any large ore body. The Wakefield exploration revealed some oxidation but apparently no ore. The $\mathrm{SE} \frac{1}{4} \mathrm{NE} \frac{1}{4}$ sec. $2 \overline{5}$, T. 42 N., R. 33 W., seems to be a more favorable area for exploration inasmuch as it is nearer the "keel" of a northwest plunging syncline.

Although the out? sok for discovery of high grade oxide ores is not good, the area may be of importance if an economically feasible process is developed by means of which the unoxidized chert siderite iron-formation can be beneficiated to yield a merchantable product. The relatively high ground, which insures easy drainage, the thin drift cover, and the proximity to the railroad are all favorable factors for exploitation by open-pit methods. 